\title{
Acta Sociologica
}

http://asj.sagepub.com

Order in Garment Markets

Patrik Aspers

Acta Sociologica 2008; $51 ; 187$

DOI: $10.1177 / 0001699308094165$

The online version of this article can be found at:

http://asj.sagepub.com/cgi/content/abstract/51/3/187

\author{
Published by: \\ (S) SAGE Publications \\ http://www.sagepublications.com \\ On behalf of: \\ Nordic Sociological Association
}

Additional services and information for Acta Sociologica can be found at:

Email Alerts: http://asj.sagepub.com/cgi/alerts

Subscriptions: http://asj.sagepub.com/subscriptions

Reprints: http://www.sagepub.com/journalsReprints.nav

Permissions: http://www.sagepub.com/journalsPermissions.nav

Citations (this article cites 28 articles hosted on the

SAGE Journals Online and HighWire Press platforms):

http://asj.sagepub.com/cgi/content/refs/51/3/187 


\title{
Order in Garment Markets
}

\author{
Patrik Aspers \\ Max Planck, Institute for the study of societies, Germany and Department of Sociology, \\ Stockholm University, Sweden
}

\begin{abstract}
The purpose of this theoretical article is to analyse the social construction of order in two connected markets in the production flow of the global garment industry. The consumer market is identified as a status market, while the production market is defined as a 'standard' market. In a 'status' market, order is maintained because the identities of actors on both sides of the market are ranked according to status, which is a more entrenched social construction than the commodity traded in the market. In a market characterized by 'standard', the situation is the reverse: the commodity is a more entrenched social construction than the identity rankings of actors in the market. The study ties together consumption and production of garments through several markets.
\end{abstract}

keywords: garment $\bullet$ globalization $\bullet$ identity $\bullet$ markets $\bullet$ sociology $\bullet$ standards

status

\section{Introduction}

There are two radically different arguments concerning how social order is created and maintained in markets. The liberal view of markets (Smart, 2003: 89-96) is that they are arenas in which monads, or hominis oeconomici, sign contracts with each other and order emerges spontaneously. The other argument is that order emerges and is maintained largely as a consequence of the state and state-implemented policies (Fligstein, 2001).

The purpose of this essentially theoretical article is to analyse a neglected issue in the economic sociological literature, namely the question of order. The concrete analysis is made in two connected markets in the production flow of the global garment industry that are embedded in each other (cf. White, 2002). The question raised is fundamental for understanding the social construction of markets as well as for understanding social order, which is a central issue that can be traced back to Hobbes (for example, Parsons, [1937]1968; Wrong, 1994; Beckert, 1996: 824-7). Social order is a matter of degree (Wrong, 1994: 9) and is defined here as the predictability of human activities and the stability of social components in relation to each other. This is another way of saying that the social constructions (Berger and Luckmann, [1966]1991) that give rise to social order are entrenched, by which I mean that they are firmly established, or in other words taken for granted, and as a consequence difficult to change (cf. Eisenstadt, 1968: 23-36). ${ }^{1}$ Social constructions are of course the result of interaction. I argue in favour of a global social constructivism; if one thinks of social constructions holistically instead of atomistically, they are related. Some constructions have become entrenched and can be used as the base of others (cf. Spence Smith, 1974; Aspers, 2005: 156, 216). When referring to social constructions one can talk only of relative entrenchment, or stability, not of absolute stability. ${ }^{2}$ 
The approach used here assumes that order in markets results from interaction of market actors; order is neither only the spontaneous result of 'an invisible hand' nor only a result of the state. Though the article focuses on order, both actors' identities and the different markets can change, and they do change, as a result of individual action as well as of external pressure. Nonetheless, change and action are conditioned upon order.

The argument is based on an analysis of two ideal-types of market that I define as 'status markets' and 'standard markets'. In a status market, order is maintained because the identities of actors on both sides of the market are ranked according to status, which is a more entrenched, i.e. more taken for granted, social construction than the commodity traded in the market, in my case, fashion garments. By status rank I mean the relative positions of actors on each side of the market as a result of past interactions and positioning. Each firm and idealtype consumer has a stable position in the rank order of their side of the fashion market interface, signalling that they have more or less status in terms of fashion. These sets of identities are relatively stable social constructions, which at least are more stable than what is traded in the market, fashion garments. A status order lacks an independent principle of evaluation. This means one cannot judge the value of a commodity outside the context of social interaction. A commodity that is tied across the market interface by high-status brand retailing chains and high-status consumers becomes a high-status commodity.

In a market characterized by standard, the situation is the reverse: the commodity, i.e. what is valued in the market, is a more entrenched social construction than the orders of identities participating in the market. It is a 'standard market' because what is valued in the market is 'measured' against a scale or rating. This is one of the assumptions that economists have when they talk of markets (Marshall, [1920a],1961: 328). I thus identify two different ways in which order is maintained in markets, ways which exclude each other and that I see as generally applicable.

Through this lens of types of order in markets it is possible to better understand the value production that is central in the fashion industry. From a historical perspective one may argue that the role of the material base, and the 'internal qualities' that are well entrenched 'in' the products or in the labour that has been used to produce the garments, has diminished and symbolic meaning, which is determined in the consumer market, has become more important for value production. ${ }^{3}$ Both a shirt of high symbolic value and a shirt of little or no symbolic value can be produced according to standardized contract. This is shown by the following quotation of production prices of garments: 'Men's Half Sleeve Shirt, one pocket flat pack, 100 per cent Cotton Polin $(92 \times 98)$ [a cotton quality] Dyed $\$ 2.80$; Printed $\$ 3.10^{\prime}$. If this shirt is sold by a low-fashion firm, it may cost $\$ 15$, but $\$ 150$ if sold by a high-fashion firm that add plenty of symbolic value to the commodity. The difference may to some extent be due to the 'quality' of the product, but is more likely due to design and marketing that endow the commodities with symbolic value. Today, the value is largely added to the product when it enters the consumer market, where it is branded. This development was predicted by Alfred Marshall (1920b: 802).

This also suggests that the global market separates production and the material costs as well as the labour production costs - of which the workers get only a fraction (Bonacich and Applebaum, 2000: 2) - from the much more value added layer of design and marketing. In other words, the circulation of economic value is still very much a local affair in the West, where the customers are, whereas the production of garments has become global.

Moreover, fashion is changing at a pace such that the stock of garments sold can be changed within three weeks. This so-called 'fast fashion' (Barnes and Lea-Greenwood, 2006) is a result of competition in the consumer market that forces those who actually produce garments to work faster. More efficient and faster chains of logistics become crucial means of competition for the branded retailers who sell garments to consumers in stores. Fast fashion is largely a 
result of the final consumer market that puts demands on the producer to keep up with the pace of change that by far exceeds the pace at which clothes are worn out.

The article begins by introducing the theoretical approach taken. This is followed by a section on the methods employed and the empirical material. The basic structure of the industry is then outlined. Which provides the foundation for the two central sections dealing with status and standard markets.

\section{Identities in markets}

Harrison White's market approach gives precedence to the question of how markets are constructed, focusing on producers. ${ }^{4}$ He describes producer markets as an array of producers (sellers) who hold niches that represent different quality-volume combinations. This implies that actors differentiate by offering products that make each of them unique within the collective identity they share as producers in the same market. A firm holding a niche has a certain reputation or prestige in the market as a result of interaction with consumers (White, 2002: 14-15, 32-33). It is through jockeying for market position that identities are compared and positioned in relation to each other. A central aspect of the market is that producers thereby generate a 'pecking order' that stabilizes the market (White, 1992). The production of the market is then an unintended consequence of the reciprocal orientation among the producers.

A market, according to White, is made up of a handful of competing producers who orient their behaviour to each other. The number of consumers, in contrast, is large. Consumers are anonymous, and the producers know little about them. The role of consumers in White's theory is reduced to saying 'yes' or 'no' to what they are offered in the market. White (2002: 177-99) argues that markets are interconnected in chains that can be focused on either upstream or downstream flows. Finally, each market is seen as a social structure that reproduces itself over time. The main difference between the neo-classical theory and the Whitean approach is that the latter stresses that producers focus on each other and that they differentiate what they offer. These Whitean insights serve as the theoretical baseline of this study.

White's market approach is not without problems. Although he does discuss commodities, this issue is clearly not the focus of his thinking. While a market gets its name from what is produced or sold (for example, the 'garment market'), its logic and practice cannot be deduced from the commodity or its material status. If the material characteristics of commodities determined the logic of markets, the production and consumption markets of garments would be almost identical, and one would in fact talk of a single market. The physical object, a garment, would be produced, bought and sold - much like stocks in exchange markets - and eventually purchased by a person in order to wear it. This is not the case, however. I argue that one must pay attention to the interplay of the logic of the market, the commodity, and how order is constructed in the market: one cannot analyse these aspects in isolation. This suggests that a commodity and its market are to some extent co-constructed. One consequence of this which I shall show - is that the commodity has different meanings in the two markets.

White speaks of a handful of producers, but in a country like India more than 30,000 exporting garment producers are registered; this empirical finding must be accounted for. I claim that the producer market can encompass this vast number of actors because it is a standard market. Market researchers frequently make use of ideal-type consumers. Acknowledging ideal-type consumers and their role in defining the commodity, as well as in constructing the market, means diverging from the Whitean framework, which, to recall, assumes that the consumer side is made up of an infinite mass of anonymous and undifferentiated buyers. Finally, in the fashion garment market, branded retailers are organized in status orders, in contrast to the quality-price order that White refers to. Figure 1 depicts the garment industry 


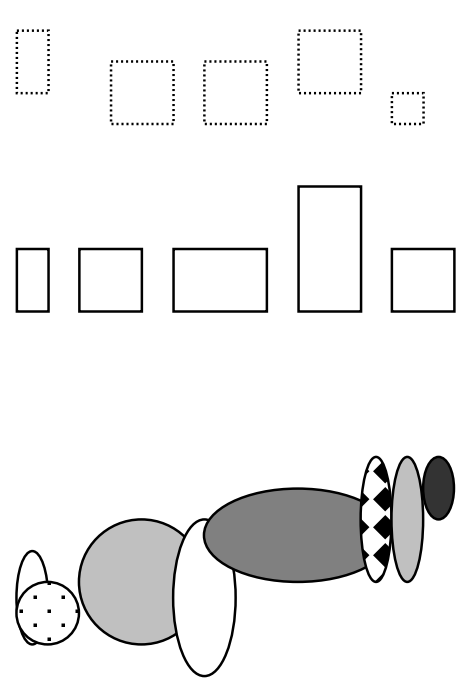

\author{
Producers \\ (suppliers, e.g., of \\ zippers)
}

Producers

(of Garment)

\author{
Branded Retailers \\ (producers of \\ symbolic value)
}

\author{
Final Consumers \\ (producers and \\ consumers of \\ symbolic value)
}

\begin{abstract}
Note: Layers of actors who share a collective identity (final consumers, branded retailers and so on) are separated from each other by a market. Each kind of actor, except final consumers, has two market roles (cf. White, 2002: 6): as producer (in the relation downstream) and as purchaser (in the relation upstream). The dotted actors in the production flow, i.e. producers of various input materials such as fabrics, are only included to show how the chain continues beyond the two markets of the chain studied in this article. The various actors in the final consumer market are shown to reflect their size and identities (including their status). Consumers are depicted as ideal-types and not as an anonymous mass.
\end{abstract}

Figure 1 Markets and actors in a production flow, schematic figure

using White's model as a baseline. The market between the branded retailers and the firms that actually manufacture the garments represent the global interface.

In the White-inspired approach used here, firms gain identities as producers (sellers), not as purchasers. This fact, I argue, is a reflection of the economic and symbolic power of the branded retailers, which is larger than the power of actors downstream (the final consumers) and upstream the production chain (garment producers). This power can be used to format consumers' perceptions, but also to determine the rules of the market for their suppliers.

Most real markets, including those analysed here, are fixed-role markets, which means that the identity of an actor in any market is fixed to only one side of the market (producer/seller or consumer/buyer). By 'identity' I mean a narrative pegged on a perceived similarity (cf. Goffman, [1963]1968; White, 1992: 74-5). This 'similarity' can be a human or a thing, but its identity is always 'pegged' by someone. In the production flow of garments, garment producers buy goods for manufacturing clothes from suppliers, e.g. fabric and other input materials, upstream in the chain. In this study, I analyse garment producer roles as producers of garments, not as purchasers of input material. Looking downstream in the chain, I analyse branded retailers' roles as purchasers of these garments. Branded retailers are, moreover, studied as sellers of these garments in the final consumer market in which they face the consumers. These roles are stable, and the incumbents (firms and consumers) stick to them. We need some additional theoretical tools for analysing the variation of consumer and 
producer markets. I claim that the theoretical distinction made here between status and standard markets can help us understand and explain the differences observed in the two markets studied.

\section{Empirical materials and methods}

The theoretical arguments of the article are supported by empirical evidence from one industry to make them easier to understand. Owing to the scope of the garment industry it is not possible to generate empirical material that is both 'thick' and still covers all of the different types of actor and markets in the industry. Nonetheless, the empirical material underlying the results of this study is drawn from 27 interviews, observations and participant observation conducted in 2001-04. It includes written material from the garment industry, business magazines and Internet sites covering various organizations, firms and marketplaces. Much of this material has been used in order to get an understanding of the industry ${ }^{5}$ - an understanding that is crucial for making the theoretical distinction between status and standard markets.

The fieldwork of the industry was carried out at factories and buying offices and in stores, and at garment fairs. I have interviewed people on the buying side (i.e. purchasers at branded retailers, importers and others), as well as CEOs (who often were also the owners of the firms) of garment producers in the less-developed production countries. My questions focused on the industry and peoples' experiences as incumbents of roles (for example, a buyer, i.e. a person who makes deals with producers about what is to be produced, and the quantity). The interviews were theoretically focused, which means that I made sure the topics I was interested in were covered, and organized as informal talks (cf. Aspers, 2004: 10). The average interview lasted for about an hour. The people I talked to were selected because of their positions, not because of their personal traits. Most of those I talked to were in more senior positions and had long experience (usually more than 5 years) of this industry.

The material was generated in India, Sweden, Turkey and the UK. The empirical work in Sweden and the UK was carried out in order to gain an understanding of the buying side of garment chains, as well as the consumer markets. India and Turkey were chosen because many garment producers are located there, Turkey being the most developed. Moreover, studying several countries enabled me to better understand the industry. This is therefore not a countrybased comparative analysis; the theoretical question does not call for analyses of countries (and this assumption was supported by my research).

The study focuses on branded retailing chains (e.g. GAP, Macy's, Zara, Topshop, H\&M, Marks and Spencer) and their suppliers (garment producers). These chains are central and dominant actors in consumer markets. Most of the people working for garment producers in Turkey and India with whom I talked are oriented towards Europe, but a few also have customers in North America. Some respondents were theoretically sampled. This means that I traced the chain from a branded retailer, through a buying office, to the firms that they use for producing their clothes. This strategy allows the actors to define who is taking part in the market and who is not, which safeguards the subjective perspective. I did not go further, to talk, for example, to suppliers of fabrics or to those who are subcontracted, that is, those located upstream of the garment producers (cf. Jacobson and Smith, 2001) in Figure 1. In other cases, I chose producers because they were small, large or because they engaged in activities such as garment fairs.

The consumer market for garments received is mostly studied by observations and participant observation, but also the consumer market appeared in the interviews with manufacturers, designers and others. There is also a large existing literature covering the field, i.e. on consumer markets, particularly for clothes and fashion (for example, Bourdieu, [1979]1984; Craik, 1993; Green, 1994; Finkelstein, 1996; Slater, 1997; Miller, 1998; Crane, 2000; Entwistle, 
2000, see also below), as well as on the garment industry (for example, Uzzi, 1997; Gereffi, 1999; Bair and Gereffi, 2001; Skov, 2003; Gereffi et al., 2005).

The empirical material was interpreted in light of the White-inspired theoretical framework. But the theoretical codes - which means codes derived from the theory used - were generated using the modified Whitean framework. However, codes and corresponding theoretical notions were also generated as a result of the empirical work. The descriptive sections and direct quotations, which due to the restricted length and the theoretical focus of the article are restricted, are used as evidence of the theoretical arguments. In other words, evidence is not restricted to direct quotations and the limited description included in the text.

\section{The final consumption market - order through status}

In the following, I discuss topics that are crucial for understanding the final consumer market for garments in contemporary Western countries, drawing mostly on the existing literature. I begin with a section on identity and consumption and follow with a section on how fashion is diffused. In the next section I discuss the commodity itself, which, finally, leads to a discussion about value and order in the fashion consumption market. All in all, this shows a market that is ordered as a function of status.

\section{Consumption and identity}

Contemporary market theories in sociology make frequent use of the notion of identity. Identity is also important in sociological research more generally (see Cerulo, 1997 and Brubaker and Cooper, 2000 for overviews). The similarity of a firm whose identity peg is made up of its logotype, staff, stores and products is sustained over time through activities and products that are connected by memory and narratives constructed using advertising, communication, and so on, of the actors in the market. Identity formation is partly related to consumption, and garment consumption is a prime example (Crane, 2000: 1-25; Entwistle, 2000: 112-39). The relationship between commodities and identity has been discussed within the so-called 'cultural economy' literature (Du Gay, 1993: 579-80; Slater and Tonkiss, 2001: 176-81; cf. Miller, 2001: 111-44). Final consumers are also seen as having reflexive capacity (Warde, 1994: 878), and consumption contributes to the development of an individual identity (Lash and Urry, 1987: 288-92; McCracken, 1988: x; Clammer, 1992: 195; Warde, 1994: 882).

\section{Fashion as constituted by interaction between objects and persons}

People interact with material objects that gain their meaning in social processes. These objects affect people's identities, but the effect can also be seen the other way around. That objects are affected by people is not a new insight. It can be seen in the seventeenth-century practices of the East India Company, which successfully introduced cotton into a British market previously dominated by wool. Its method was to extend favours and services to 'prominent and useful people; samples of Indian goods were distributed where they would attract attention and create fashionable demand' (Douglas, 1969: 29). Thus, not all customers are of equal worth and some are targeted because they are assumed to influence other consumers. All this was done by producers who knew that existing or potential consumers must be reached through the 'right' people (Moor, 2003: 46), which includes the construction of ideal-type consumers, or 'virtual consumers' (Carrier and Miller, 1998), based on more or less real actors. Fashion, seen from the side of the consumer, often begins among those who are perceived to be trendsetters, and these trends later spread to other groups. Yuniya Kawamura (2006) has shown that even saleswomen (a popular occupation in some circles of Japanese youths) working at certain stores can add substantial meaning to garments when they wear them in the store, such that consumers can observe them and ultimately buy the garments. 
This idea is expressed by Simmel's ([1904]1971) 'trickle down' theory of fashion, though he of course saw this happening within a class structure rather than among 'icons' and trendsetters. Today, 'prominent and useful people' or 'opinion leaders' may be found not only in the vicinity of the royal family or the upper class, but also among, say, the gay population, celebrities or clubs in Los Angeles or Manchester (cf. McCracken, 1988: 80-1). The role of celebrities in particular has increased over time (McCracken, 1989; Aggrawal and Kamakura, 1995). This is supported by a comment from the head of one buying department who said that 'these days, trends travel extremely quickly over the world. One immediately notices when icons like Beckham or Madonna are wearing something new'. That this can take place 'immediately' is due to the transmission by the fashion and gossip press, as well as the Internet. Contemporary trends are also more circular, and ideas are picked up and used from both the top and the bottom. Over time, street subcultures have also become highly important as sources for new products and ideas in many cultural industries such as fashion (Muggleton, 2000; Slater and Tonkiss, 2001: 168-71; Hodkinson, 2002; cf. Huat Chua, 1992: 123-4). Craik (1993: 217) calls this the 'trickle-up' process, in contrast to the 'trickle-down' process described by Simmel.

There are observable market transactions that bind producers, commodities and consumers to each other. This stability of interaction, which means that certain types of consumers buy clothes from certain types of firms, creates order. Several examples of how brands and types of actors have constituted each other are given by, for example, Alison Goodrum (2005). Goodrum informs us how, in the 1980s, Paul Smith became the brand of 'power broker and young professional dressing' (2005: 140). In a similar way: 'The yuppie [who in the 1980s] wanted to transform hefty salaries and large bonuses into investments and goods that would demonstrate Bourdieuian "honorability"' (Goodrum, 2005: 135) found a producer that could help to create this identity in garments and accessories from Mulberry. We often think of this process in terms of commodities defined through the selling and buying (and wearing) of high-status actors. The process can also go in the other direction, however: actors with identities of low standing may 'contaminate' the commodity and thereby diminish its status. Thus, a commodity may go out of fashion when too many people begin to use it, when people in the provinces or small children begin to use it (Meyer and Anderson, 2000), and when it is sold in cheap stores and through mail-order catalogues.

One conclusion that can be drawn from the discussion so far is that though fashion trends are difficult to predict, they can be changed. Actors on both sides of the market - producers and consumers - have the power to change current patterns. Both sides can try to couple and decouple, that is, shift those they interact and collaborate with in the market, thereby reconstituting what is in fashion. As a result, the identities of actors in the market are affected by the changes that occur in the status hierarchy (Podolny, 2005). Garment sellers, branded retailers and others come up with new products, put objects on display, advertise them and create brands, as Alfred Marshall (1920b: 300-2) pointed out. However, only as a result of consumers' choices - and trendsetters' choices in particular - to buy and wear garments will certain garments come to be in fashion and others not (cf. Beaudoin et al., 2003). No one is in total control of the social game being played, especially since actions are seldom made in concert. Larger players, typically independent design houses, fashion magazines, larger branded retailers and branded marketers, usually have more say (Entwistle, 2000: 220-36), and they have at least some power to affect not only the result of the game, but also its rules (Bourdieu, [1992]1996: 254-5). Power to influence fashion is a function of size and status. A firm's identity in the market, including its history and status position, is crucial for its ability to spread its idea of fashion. So far I have looked at this relationship from both sides, that is, buyers and sellers, but I have not yet directly discussed the product. How can one describe fashion garments? 


\section{Order, value and identity in status markets}

All garments have basic functions connected with the social construction of the materiality, such as protection and keeping their wearer warm. However, these aspects do not define fashion garments. It is clear that consumers do not pay primarily for quality, in terms of longlasting fabrics and so on (though naturally this is part of what gives a commodity value in the eyes of consumers; see White, 1981). Many clothes are left in the wardrobe before they are worn out or are recycled to developing countries. Also this, I claim, shows that the symbolic value of the commodity matters more than the material dimension it is pegged on.

The symbolic value of commodities can be understood as a function of a network of connections generated by sellers and buyers in the market, as indicated by the discussion of fashion earlier. To unfold this idea, one must consider how value is created in markets. This means going beyond a simple semiotic analysis and bringing in social position and status.

The value of a commodity is created in relation to ideal-type actors (McCracken, 1988: $71 \mathrm{ff}$; Beckert and Rössel, 2004). A commodity has meaning, but this meaning is constituted in relation to its horizon (or 'fringe', as William James called it). When a certain brand of garment (or even a certain type of brand) is awarded high status by consumers and producers, it is because it has a 'fringe': for example, being seen as 'urban young Asiatic'. The constitution of a commodity is a result of who sells it and who wears it (and their status), as well as its relations to other commodities as perceived by the actors in the market (cf. McCracken, 1988: 74; Slater, 2002: 71-2).

In garment consumption markets, ideal-type consumers' and branded retailers' identities, as well as different brands' identities, are fairly entrenched, meaning that they are more or less taken-for-granted social constructions that occupy positions in the respective status hierarchies of the two sides of the market. Some retailers and brands have more status than others, and an analogous status order exists among ideal-type consumers. It is my thesis that the status orders established in the market are more stable than the products themselves, namely fashion garments. The fashion products themselves, the objects that are produced (such as various kinds of skirt), however, are less so; fashion changes quickly. The sociological question is how to theorize these social phenomena.

In order to understand what is going on, we therefore have to focus on the theoretical notion of status in addition to the aforementioned discussion of the diffusion of fashion. If a garment is sold by a high-fashion-status firm and is worn by consumers identified as influential and trendsetting, it is much more likely to become fashionable than it is if consumers with low status (for example, the elderly) buy the same clothes.

It is easy to observe the interaction between retailers' and brands' identities, on the one hand, and the actors representing certain ideal-type consumers, on the other. Fashion is predominantly visual, and just being around certain people or being in the places they frequent provides information about current fashion. However, the visual dimension reaches further than this. Store design and display, and the plastic shopping bags carried by different kinds of people (ideal-type consumers), are also important in the construction of fashion. The efforts of brands and branded retailers to promote certain styles are reflected in the location of stores, the way the clothes are hung within them, the lighting, the music and the style of the salespersons. All of this is strengthened by advertising and editorial fashion stories in magazines (McCracken, 1988: 79). Through this relationship, actors see garments that hang or are used together, and which transmit status to each other. In practice, this often means that high-status retailers and brands exchange status with one another, whereas low-status retailers and 'non-brands' mutually reinforce their lack of status. This is a form of 'interaction' between people and objects which is perceived as having certain meanings. One can conclude that the visual dimension is fundamental in creating the perception of status orders in the market. In this market, firms know their competitors and relate to each other (White, 2002). This is 
expected in status markets: without it, it would be hard to make the relational dimension of status a factor of order.

To sum up this discussion, a commodity gets its identity, and thereby its value and price, in relation to observable patterns of interaction between a brand name and its wearers. Through interactions such as these, actors, branded retailers and consumers also manifest themselves and reconstitute their own identities, as well as the identities of the garments they wear. In accordance with this thesis, the value of products, as seen from the consumers' perspective, comes more from their social ties, position and status in the respective status order, and less from, say, the types of fabric used (cf. Marshall, 1920b: 56-7, 799-803). This makes us understand fashion and thus what is behind the purported 'explanations' by semiotic thinkers who identify meaning in the text (garments).

Moreover, it may appear strange that the identities of firms selling garments and the idealtype consumers are considered to be stable in relation to each other, but the important point is that these orders are at least more stable than the commodity, the fashion garment. At the top of the consumers' fashion status ladder, to make some brief statements of this particular market, are royalty and celebrities, such as soccer players (and their wives), musicians and movie stars. At the lower end, one finds children, elderly and others who are seldom seen as trendsetters.

A fashion garment is more a function of the coupling of high-status actors from the two sides (orders) of the market than the other way around (cf. Aspers, 2005); that is, the actors are functions of the commodity. Nonetheless, no single actor can determine what other actors do; a branded retailer cannot, for example, control who will buy their clothes. They can, however, use advertising, location of stores, styling of their sales personnel and pricing to 'signal' who their intended buyers are. Burberry is one example of a brand that was 'hijacked' by soccer hooligans, i.e. a firm's clothes can gain meaning far beyond what a firm intends. Thus, the 'objectified' meaning of the garments is a somewhat unintended effect of the interaction between producers and consumers.

\section{The industrial production market - order through standard}

I now turn to the social order of garment producers' identities. To understand them, and more importantly to understand how order is constructed in this market, one must also consider the purchasers of the products and the products. Garment producers' market identities derive from their commitment as producers and their interactions with branded retailers, who they face downstream in the production chain. In contrast to the consumer market, order in the garment production market is directly connected with the 'commodity'. However, the commodity is more like a standard consisting of a price-quality-delivery function, which, given one has reached its threshold, means that garment producers can compete by improving quality or by cutting prices. This standard is largely determined by those who buy, i.e. the retailers, reflecting their superior power. Garment producers in this market acquire their identities in relation to how well they meet the standard (cf. White, 2002: 78-9). Standard ('quality') functions as a valuation ordering (White, 1992: 29; Callon et al., 2002; Favereau et al., 2002; Aspers, 2007; Diaz-Bone, 2007) regarding a certain product or service. The standard becomes more or less taken for granted, which means that order is maintained as a result of the stability of the standard, and not as a result of interaction patterns, as is the case in status markets; both forms are, of course, 'cognitive'.

The processes of garment production and trade are embedded in international agreements, conventions and business culture. The legal aspects of trade, most notably the contract, exemplify this. Buyers of garments monitor manufacturers both before and during the production process and are, by and large, in control of production. This monitoring includes financial, 
legal, technical and social aspects. I asked a garment producer whether the buyers return to the factory every now and then to check the production. She replied:

$[\mathrm{N}] \mathrm{o}$, the buyers [who come from the main office] come only once or twice a year. The [representatives from] buying houses [who are employed in the production country] come very often; they come to see the fabric, the printing, the process; they will check the sizes, we will send them samples; they will check the measurements to see that they are according to the requirements.

A contract between producer and buyer often allows the latter to show up at virtually any time to conduct an inspection. It is clear from my own observations in factories that these inspections focus on how the producers maintain the quality of the garments produced.

Garment producers use references from other purchasers and samples of products to prove their ability to meet certain standards of price and quality, which enables them to compete. Garment producers also come into contact with the branded retailers through agents or the retailers' buying offices, and they may then get the chance to make a test order, and perhaps later a full order, given that the buyer is pleased with the test. Producers of garments do not merely compete on price, assuming that the other requirements have been met. It may be said, instead, that they compete on quality assuming that they are equal in other terms, including price. Prices, usually set in US dollars, tend to be rather fixed. As explained by one buyer discussing the negotiation process, 'prices are not a problem, it can be one or a few cents up or down'. In addition, the costs of all input material are also known by the buyer, who describes their price in terms of a 'stock exchange'. I asked if this effectively means that buyers determine the profit margin, and received the following reply: 'indirectly, we [the retailers] $\mathrm{do}^{\prime}$. One may even say that the prices are decided in the consumer market, and that the effect of these prices, as it were, travels backwards to the producers of garments. One producer of garments explained that buyers target prices, 'and we see if we can do it or not'. Buyers also inform garment producers about prices in other parts of the world. This is what a garment producer was told by a buyer: '[N]ow we are buying from China at that price and Bangladesh at this price.' To quote prices from competing producers is one way in which information is spread across the industry, but also indicates the competitive logic of the market. Prices in final consumer markets differ between localities (markets), but in the global producer market of garments, producers across the world compete with each other, and competition is also stronger in this standard market than between branded retailers in the status market where they sell the finished garments. The prices in the producer market do not refer to certain garments, but to producing and delivering at a certain price.

Producers of garments in this 'standard' market do not compete in the same way as branded retailers in a status market do, by aesthetic differentiation, but by having a better pricequality-delivery combination. This is essentially a standard determined by the buyers, reflecting their power. One buyer explains her view on what the manufacturers must have in order to be of interest to her: '[T]hey must be able to handle the volumes, and obviously, the right price level and of course and ... they [must] have a certain level of quality.' The following is a statement from a manufacturer who explains the typical response to this 'standard': '[W]e try our best to negotiate with buyers and give the best price, and make sure that the supplier is of the right quality, and delivers on time.' Thus, the aspects of price and quality cannot be separated. I asked a buyer what she thought characterized a good producer. She replied: '[A] good producer is [one who] has good products, the right price, secure delivery and communicates well. And then it may be that the garment producer has design input. But the first four are the most important.' This finding emphasizing the standard of the market to which actors on both sides orient is in line with previous research (Thaver and Wilcock, 2006). While the role of design is included in the equation, this matters less than the more standardized aspects for establishing, maintaining and evaluating a relationship. Failure to meet these requirements 
may result in termination of the relationship. This shows that the role of status matters little in this market.

Differentiation, as already mentioned, is an important aspect in a status market and is a condition for carving out a niche in the market. In standard markets, actors try to outperform their rivals by scoring higher on the standard measurement, which often means that they focus on price, given that the other demands are often absolute. One may in fact say that the producers in standard markets are similar when it comes to self-presentation, how work is organized and pricing. This is not to neglect variation among them, but rather to recognize that the variation is not primarily oriented to status.

Similarities between producers are seen clearly in the way they market themselves. The information material that producers send to potential buyers puts the spotlight on production capacity; how short the lead time is; what kind and quantity of machines they have; how well they check quality; and their relations to purchasers. If pictures are included in garment producers' PR material, they often show the factory from the outside and some pictures of production. In India, when travelling in the industrial districts, it is often impossible from the outside even to recognize what is going on behind the walls; signs or other means of identifying the business are often missing. This kind of 'marketing', i.e. in which they do not differentiate regarding fashion level, would be unthinkable on the high street. Moreover, the production technology is not a secret in this industry. The secret is the design of the fashion garments, since it is primarily through design, as an integrated component of a firm's identity, that leading branded retailers can maintain their high status market niches. These niches are more the most economically profitable in a market (Podolny, 2005).

Also in this market, which is ordered around a standard, all actors that can meet it compete. They are not 'protected' by having a market niche and being involved in a form of monopolistic competition that is characteristic of firms in a consumer market with niches (cf. White, 2002). It is impossible to judge how many producers - for example, out of the 30,000 garment producers in India - compete directly. It is clear, however, that they do not know about each other in the same way as branded retailers do. Thus, their orientation is to the standard (because this is stable and a good predictor of what it takes to make it in this market). In the status market, firms orient themselves much more actively to each other (Aspers, 2007).

What about the commodity in this type of market? While one would assume this to be a market for fashion products, this is in fact not the case. The contract between branded garment retailers and producers of garments is not primarily about the physical products; it is more correct to view it as a service contract. This is because decisions about what to produce, how it should look, and so on, are made by the more powerful purchaser, while the contract deals with the production facilities, delivery and related issues - aspects that constitute the standard (which represent the institutional interest of the buyers). Thus, the purchasers are most concerned with the production facilities, including the skills of the workers, and they may book the factory capacity before they know exactly what they want to produce. In this market, the physical aspect of the garment is conceptualized in terms of quality in the service contract. Everyone in the business knows the standard, and the identity of the produce of garment is determined by how well they perform in relation to it.

\section{Conclusions}

This theoretical article introduces the general distinction between status and standard markets, and though this distinction gets support from this article, there is need for more research to confirm this, and to test the generality of the thesis. The distinction has been developed to account for the differences between the producer markets and the final consumer markets of garments that I have studied. In the consumer market, order is a function of stable ranks of 
identities of ideal-type consumers (for example, 'young professionals' and 'urban women') and firms. Both the ideal-type consumers and the firms - on each side of the market interface - are identified in relation to each other, some having more status than others. These orders are fairly stable and at least more entrenched social constructions than the product. Order in production markets for garments, on the other hand, is a function of stable standards: the standard in the market is more entrenched than actors' identities. Thus, order in standard markets is constructed in the opposite way from how it is constructed in status markets.

There are of course many similarities between these two ideal-type markets. Both, for example, are fairly stable and enduring social structures. But, as has been argued, a social construction is stable only in relation to at least one other, less stable (less entrenched) social construction. Furthermore, actors in both markets take them for granted. Even actors who are not 'born' in the market will 'take its order for granted' soon after their entrance into it. Through their actions they will reinforce or reconstruct the market. This form of 'cognitive path dependency', which means that actors take the constructions making up the market for granted, makes them more stable (cf. Berger and Luckmann, [1966]1991). ${ }^{6}$ Newcomers may of course affect the market, but in larger markets even the largest single actor is still a very small player. They are both fixed role markets, and in this sense they are two kinds of the most prolific forms of market.

There are also differences. The two markets differ in structure: one is a consumption or 'edge' market, the other a production market; one is more local and the other more global. While important, these aspects are not the focus of this article, nor do they seem to have direct relevance for how order is maintained in markets.

Status markets are typically found where aesthetic judgments are common (cf. Warde, 2002: 192). Examples of status markets can be found in many different industries. I hypothesize that standard markets, on the other hand, include commodity markets in which the principle of evaluating the commodity is clear and stable, but also in technology-driven industries (cf. Schmidt and Werle, 1998). Today, not only fashion garment markets should be seen as 'status' markets, also markets for cars, furniture, art and many other 'markets' could be analysed using this tool. Other markets, such as the market for crude oil, gold and highly standardized products, are best analysed using the idea of a standard market. Obviously, no empirical market will be a pure instance of any of these theoretical notions.

This study contributes to the existing literature on the sociology of the market by outlining aspects that need more attention if a more coherent sociological theory of markets is to emerge. While there are a growing number of studies of real markets (e.g. Dulsrud and Grønhaug, 2007) they seldom clarify what key distinctions should be made. In this article, I argue that the distinction between standard and status markets is profound.

I conclude by reflecting on points that are relevant to the sociology of markets. Most market actors work in an uncertain and aggressive business environment and hence have an interest in shaping the market so that its structure suits their purposes. Size and status often translate into power. In standard markets, powerful players can improve their positions by imposing standards on their counterparts, and thereby increase inequality. The state can be a vehicle for groups with different interests (cf. Fligstein, 2001; White, 2002: 88), for example in creating standards, including quotas, trade rules, and so on. However, the theoretical argument focuses on the standard and status markets, and does not depend on the existence or intervention of states.

These remarks can be seen in the context of the structural change that this industry has undergone. For example, some production still exists in the Occident (cf. Arpan et al., 1981; Gereffi, 1999), but it often uses advanced technology (Abernathy et al., 1995: 177). In addition, immigrants from certain countries have started up garment production both in Europe (Morokvasic, 1993) and in the United States (Bonacich and Applebaum, 2000). One consequence 
is that production, on the one hand, and design and marketing, on the other, have become separated. Today, garment production is a global market, and it is a result of the historical shift from local production (organized within a single firm) to market coordination and outsourcing (Gereffi et al., 2005). Outsourcing of production is prevalent, and a large share of production takes place in countries because they can offer low wages (Abernathy et al., 1995).

The globalization of the industry has repercussions for market structure because identity formation is central to branded retailers in the garment industry. Identity formation is the task of designers and people in marketing divisions (Taplin, 1994) who contract advertising agents to do their practical work. Production is merely a reflection of these activities and is no longer the main issue among managers of large branded retailers; it is mainly about getting the lowest price, given constraints such as quality, quotas, lead times, and so on.

\section{Notes}

I am grateful for comments by Jens Beckert, Caroline Dahlberg, Guido Möllering, Geny Piotti, Armin Schäfer, Richard Swedberg and Raymund Werle and, not least, the two anonymous reviewers. I gratefully acknowledge financial support for the research reported here from the Axel and Margaret Ax:son Johnson Foundation.

1. For a general discussion of social constructions, see, e.g., Searle (1995), Collin (1997) and Hacking (1999).

2. Some social constructions are more deeply entrenched, such as the laws of logic, and are assumed also by actors who hold opposing views.

3. The approach I suggest implies that the 'material' qualities, which of course matter in both production and consumption markets, must also be seen as social constructions (cf. Latour, 1996). This suggests that status is likely to be an even more frequently encountered principle governing social order in markets in the future.

4. In addition to White's own works (e.g. 1981, 1992, 2002, 2005), there are many studies which are related to his approach (e.g. Aspers, 2005; Podolny, 2005).

5. What I present here excludes issues such as 'sweatshops', quotas, industrial politics and ethical labelling.

6. I am grateful to Jens Beckert, who suggested this term.

\section{References}

Abernathy, F. et al. (1995) 'The Information-Integrated Channel: A Study of the U.S. Apparel Industry', Brookings Papers on Economic Activity 1995: 175-246.

Aggrawal, J. and Kamakura, W. (1995) 'The Economic Worth of Celebrity Endorsers: An Event Study Analysis', Journal of Marketing 59: 56-62.

Arpan, J., De La Torre, J. and Toyne, B. (1981) 'International Developments and the U.S. Apparel Industry', Journal of International Business Studies, (Winter) 12: 49-64.

Aspers, P. (2004) Empirical Phenomenology. An Approach for Qualitative Research. The Methodology Institute, London School of Economics.

Aspers, P. (2005) Markets in Fashion. A Phenomenological Approach. London: Routledge.

Aspers, P. (2007) 'Wissen und Bewertung auf Märkten', Berliner Journal für Soziologie 4: 431-49.

Bair, J. and Gereffi, G. (2001) 'Local Clusters in Global Chains: The Causes and Consequences of Export Dynamism in Torreon's Blue Jeans Industry', World Development 29: 1885-903.

Barnes, L. and Lea-Greenwood, G. (2006) 'Fast Fashioning the Supply Chain: Shaping the Research Agenda', Journal of Fashion Marketing and Management 10, 3: 259-71.

Beaudoin, P., Lachance, M. and Robitaille, J. (2003) 'Fashion Innovativeness, Fashion Diffusion and Brand Sensitivity Among Adolescents', Journal of Fashion Marketing and Management 7: 23-30.

Beckert, J. (1996) 'What is Sociological About Economic Sociology? Uncertainty and the Embeddedness of Economic Action', Theory and Society 25: 803-40. 
Beckert, J. and Rössel, J. (2004) 'Reputation als Mechanismus der Reduktion von Ungewissheit am Kunstmarkt', Kölner Zeitschrift für Soziologie und Sozialpsychologie 56, 1: 32-50.

Berger, P. and Luckmann T. ([1966]1991) The Social Construction of Reality. A Treatise in the Sociology of Knowledge. London: Penguin Books.

Bonacich, E. and Applebaum, R. (2000) Behind the Label. Inequality in the Los Angeles Apparel Industry. Berkeley, CA: University of California Press.

Bourdieu, P. ([1979]1984) Distinction: A Social Critique of the Judgment of Taste. Cambridge, MA: Harvard University Press.

Bourdieu, P. ([1992]1996) The Rules of Art, Genesis and Structure of the Literary Field. Stanford, CA: Stanford University Press.

Brubaker, R. and Cooper, F. (2000) 'Beyond "Identity"', Theory and Society 29: 1-47.

Callon, M., Méadel, C. and Rabeharisoa, V. (2002) 'The Economy of Qualities', Economy and Society 31: 194-217.

Carrier, J. and Miller, D. (1998) Virtualism: A New Political Economy. Oxford: Oxford University Press.

Cerulo, K. (1997) 'Identity Construction, New Issues, New Directions', Annual Review of Sociology 23: 385-409.

Clammer, J. (1992) 'Aesthetics of the Self, Shopping and Social Being in Contemporary Urban Japan', in R. Shields (ed.) Lifestyle Shopping: The Subject of Consumption, pp. 195-215. London: Routledge.

Collin, F. (1997) Social Reality. London: Routledge.

Craik, J. (1993) The Face of Fashion. Cultural Studies of Fashion. London: Routledge.

Crane, D. (2000) Fashion and Its Social Agenda. Class, Gender, and Identity in Clothing. Chicago, IL: University of Chicago Press.

Douglas, A. (1969) 'Cotton Textiles in England: The East India Company's Attempt to Exploit Developments in Fashion 1660-1721', Journal of British Studies 8: 28-43.

Diaz Bone, R. (2007) 'Qualitätskonventionen in ökonomischen Feldern', Berliner Journal für Soziologie 4: 489-509.

Du Gay, P. (1993) “"Numbers and Souls”: Retailing and the De-Differentiation of Economy and Culture', British Journal of Sociology 44: 563-87.

Dulsrud, A. and Grønhaug, K. (2007) 'Is Friendship Consistent with Competitive Market Exchange? A Microsociological Analysis of the Fish Export-Import Business', Acta Sociologica 50: 7-19.

Eisenstadt, S. (1968) 'The Development of Sociological Thought', in D. Sills (ed.) International Encyclopedia of the Social Sciences, vol. 15, pp. 23-36. London: Macmillan.

Entwistle, J. (2000) The Fashioned Body. Fashion, Dress and Modern Social Theory. Cambridge: Polity Press.

Favereau, O., Biencourt, O. and Eymard-Duvernay, F. (2002) 'Where Do Markets Come From? From (Quality) Conventions!' in O. Favereau and E. Lazega (eds) Conventions and Structures in Economic Organization: Markets, Networks and Hierarchies, pp. 213-52. Cheltenham: Edward Elgar.

Finkelstein, J. (1996) After a Fashion. Melbourne: Melbourne University Press.

Fligstein, N. (2001) The Architecture of Markets. An Economic Sociology for the Twenty-First Century Capitalist Societies. Princeton, NJ: Princeton University Press.

Gereffi, G. (1999) 'International Trade and Industrial Upgrading in the Apparel Commodity Chain', Journal of International Economics 48: 37-70.

Gereffi, G., Humphrey, J. and Sturgeon, T. (2005) 'The Governance of Global Value Chains', Review of International Political Economy 12: 78-104.

Goffman, E. ([1963]1968) Stigma: Notes on the Management of Spoiled Identity. Ringwood: Penguin Books.

Goodrum, A. (2005) The National Fabric: Fashion, Britishness, Globalization. Oxford: Berg.

Green, N. (1994) 'Art and Industry: The Language of Modernization in the Production of Fashion', French Historical Studies 18: 722-48.

Hacking, I. (1999) The Social Construction of What? Cambridge, MA: Harvard University Press.

Hodkinson, P. (2002) Goth: Identity, Style and Subculture. Oxford: Berg.

Huat Chua, B. (1992) 'Shopping for Women's Fashion in Singapore', in R. Shields (ed.) Lifestyle Shopping: The Subject of Consumption, pp. 114-35. London: Routledge.

Jacobson, T. and Smith, G. (2001) Cotton's Renaissance: A Study in Market Innovation. Cambridge: Cambridge University Press.

Kawamura, Y. (2006) 'Japanese Teens as Producers of Street Fashion', Current Sociology 54: 784-801. 
Lash, S. and Urry, J. (1987) The End of Organized Capitalism. Cambridge: Polity Press.

Latour, B. (1996) Aramis or the Love of Technology. Cambridge, MA: Harvard University Press.

Marshall, Alfred ([1920a]1961) Principles of Economics, edited with annotations by C. W. Guillebaud, 2 vols. London: Macmillan.

Marshall, A. (1920b) Industry and Trade. A Study of Industrial Technique and Business Organization; and of Their Influences on the Conditions of Various Classes and Nations. London: Macmillan.

McCracken, G. (1988) Culture and Consumption: New Approaches to the Symbolic Character of Consumer Goods and Activities. Bloomington, IN: Indiana University Press.

McCracken, G. (1989) 'Who is the Celebrity Endorser? Cultural Foundations of the Endorsement Process', Journal of Consumer Research 16: 310-21.

Meyer, D. and Anderson, H. (2000) 'Preadolescents and Apparel Purchasing: Conformity to Parents and Peers in the Consumer Socialization Process', Journal of Social Behavior and Personality 15: 243-57.

Miller, D. (1998) A Theory of Shopping. Ithaca, NY: Cornell University Press.

Miller, D. (2001) The Dialectics of Shopping. Chicago, IL: Chicago University Press.

Moor, E. (2003) 'Branded Spaces: The Scope of "New Marketing"', Journal of Consumer Culture 3: 39-60.

Morokvasic, M. (1993) 'Immigrants in Garment Production in Paris and in Berlin', in I. Leight and P. Bhachu (eds) Immigration and Entrepreneurship. Culture, Capital and Ethnic Networks, pp. 75-95. New Brunswick: Transaction Publishers.

Muggleton, D. (2000) Inside Subculture. The Postmodern Meaning of Style. Oxford: Berg.

Parsons, T. ([1937]1968) The Structure of Social Action, vol. I. New York: Free Press.

Podolny, J. (2005) Status Signals. A Sociological Study of Market Competition. Princeton, NJ: Princeton University Press.

Schmidt, S. and Werle, R. (1998) Coordinating Technology: Studies in the International Standardization of Telecommunications. Cambridge, MA: MIT Press.

Searle, J. (1995) The Construction of Social Reality. New York: Free Press.

Simmel, G. ([1904]1971) 'Fashion', in D. Levine (ed.) George Simmel on Individuality and Social Form, pp. 294-323 Chicago, IL: Chicago University Press.

Skov, L. (2003) 'Fashion-Nation: A Japanese Globalization Experience and A Hong Kong Dilemma', in C. Jones, A. Leshkowich and S. Niessen (eds) Re-Orienting Fashion: The Globalization of Asian Fashion, pp. 215-42. Oxford: Berg.

Slater, D. (1997) Consumer Culture and Modernity. Cambridge: Polity Press.

Slater, D. (2002) 'Capturing Markets From the Economists', in P. Du Gay and M. Pryke (eds) Cultural Economy, Cultural Analysis and Commercial Life, pp. 59-77. London: Sage.

Slater, D. and Tonkiss, F. (2001) Market Society, Markets and Modern Social Theory. Cambridge: Polity Press. Smart, B. (2003) Economy, Culture and Society. Buckingham: Open University Press.

Spence Smith, T. (1974) 'Aestheticism and Social Structure: Style and Social Network in the Dandy Life', American Sociological Review 39: 725-43.

Taplin, I. (1994) 'Strategic Reorientations of U.S. Apparel Firms', in G. Gereffi and M. Korzeniewic (eds) Commodity Chains and Global Capitalism, pp. 205-22. Westport, CT: Praeger.

Thaver, I. and Wilcock, A. (2006) 'Identification of Overseas Vendor Selection Criteria Used by Canadian Apparel Buyers. Is ISO 9000 Relevant?' Journal of Fashion Marketing and Management 10: 56-70.

Uzzi, B. (1997) 'Social Structure in Interfirm Networks: The Paradox of Embeddedness', Administrative Science Quarterly 42: 35-67.

Warde, A. (1994) 'Consumption, Identity-Formation and Uncertainty', Sociology 25: 878-98.

Warde, A. (2002) 'Production, Consumption and "Cultural Economy"', in P. Du Gay and M. Pryke (eds) Cultural Economy, Cultural Analysis and Commercial Life, pp. 185-200. London: Sage.

White, H. (1981) 'Where Do Markets Come From', American Journal of Sociology 87: 517-47.

White, H. (1992) Identity and Control: A Structural Theory of Social Action. Princeton, NJ: Princeton University Press.

White, H. (2002) Markets from Networks: Socioeconomic Models of Production. Princeton, NJ: Princeton University Press.

White, H. (2005) Social Construction of Flows: Price Profiles Across Producers Gear to Market Context Upstream, Downstream and Cross-Stream. ISERP WP, 01/05. New York: Columbia University.

Wrong, D. (1994) The Problem of Order. What Unites and Divides Society. New York: Free Press. 
Biographical Note: Patrik Aspers is research fellow at the Max Planck Institute for the Study of Societies in Cologne and Associate Professor of Sociology at Stockholm University. His research focuses on economic sociology and sociological theory. Aspers is the author of Markets in Fashion: A Phenomenological Approach (Routledge, 2005).

Address: Max Planck Institute for the Study of Societies, Paulstr. 3, 50676 Cologne, Germany. [email: aspers@mpifg.de] 